\title{
Virin HSK and Helicovex SK - efficacy and safety of baculovirus-based bioinsecticides
}

\author{
Vladimir Ismailov ${ }^{1}$, Irina Agasjeva ${ }^{1}$, Grigory Ananko ${ }^{2}$, and Alexey Kolosov ${ }^{2 *}$ \\ ${ }^{1}$ All-Russian Research Institute of Biological Plant Protection, Federal Agency of Scientific \\ Organizations, 39, Krasnodar, Russia \\ ${ }^{2}$ FBRI State Research Center of Virology and Biotechnology "Vector" Rospotrebnadzor 630559, \\ Koltsovo, Novosibirsk region, Russia
}

\begin{abstract}
Insect pest control is a key mechanism to give humans advantage over insects in competition for food resources. Bioinsecticides are highly virulent in target insects, can control their populations and prevent a sharp increase in their number. The bioinsecticide Virin HSK was created in FBRI SRC VB "Vector". Helicoverpa zea single nuclear polyhedrosis virus strain HS-18 is the active basis for Virin HSK. Here we studied the effectiveness of Helicovex SK and Virin HSK bioinsecticides as cotton bollworms control agent in comparison with the chemical insecticide Pirinex, $\mathrm{CE}$ and determined the safety of these insectisides for the entomophage. The flow rate of the working fluid was $200 \mathrm{l} / \mathrm{ha}$. Helicovex SK and Virin HSK protected soybean during bean ripening and corn in the period from wax ripeness to harvesting. Helicovex SK and Virin HSK had higher efficiency than Pirinex KE.
\end{abstract}

\section{Introduction}

Insect pest control is a key mechanism to give humans advantage over insects in competition for food resources. Nonselective insecticides misbalance natural and agroecosystems and often pollute environment and irreversibly damage the biosphere. To improve ecological situation and develop organic farming, it is necessary to gradually abandon the chemical plant protection products in favor of environmentally friendly bioinsecticides. High efficiency and safety for humans and environment makes viral insecticides one of the most promising components of integrated protection of vegetables, fruit and grain crops. [1, 2, 3]. Entomopathogenic baculoviruses may also be considered as natural regulators to continuously control pest insect population at economically and environmentally safe levels $[4,5]$.

Baculovirus-based bioinsecticides are highly virulent in target insects and prevent a sharp increase in their number $[6,7,8]$. Their species-specificity guarantees the safety of non-target insects $[9,10,11]$. Baculoviruses can spread not only horizontally (from one insect to another) [12], but also vertically (from parent to filial generation) $[5,13]$, and therefore have prolonged effect which lasts for several years. Despite obvious advantages

\footnotetext{
${ }^{*}$ Corresponding author: kolosov@vector.nsc.ru
} 
of bioinsecticides, their use in crop production, including corn, is still limited. [6, 14, 15 , $16,17,18]$.

One of the most common and dangerous pest in global corn production is cotton bollworm Helicoverpa armigera (Hübner, 1808). The proportion of affected corn plants sometimes reaches $50-60 \%$ with significantly reduced number of ears, weight and grain quality.

Here we assess the efficiency and safety of the bioinsecticides Helicovex SK (Andermatt Biocontrol, Switzerland) and Virin HSK, (FBRI SRC VB Vector, Rospotrebnadzor, Russia) in comparison with chemical insecticide Pirinex $\mathrm{KE}$ (Makhteshim-Agan Industries Ltd., Israel).

\section{Materials and methods}

On agricultural lands near Krasnodar (Russia), which belong to the II-zone of the black soil of forest-steppe and steppe regions in North Caucasian crop cultivation region, we carried out a microplot experiment to measure the effect of two bioinsecticides (Helicovex SK, Virin HSK) and a chemical insecticide Pirinex KE on cotton bollworm (Heliothis armigera $\mathrm{Hbn}$ ). Each insecticide was tested three times on randomly localized 15-square-meter plots. Pulverex knapsack sprayer with a 0.3 1/15-square-meter plots flow rate of a working fluid (or $200 \mathrm{l} / \mathrm{ha}$ ) was used for insecticide treatment of corn and soybean at various stages of the growing season.

Leached super-powerful low humus black soil of the area (humus content $-3.8 \%$, mechanical composition - heavy loam, $\mathrm{pH}=6.8$ ) was plowed $25-27 \mathrm{~cm}$ deep with subsequent pre-sowing cultivation. Every experimental plot was weeded manually, and no fertilizers were applied. The seeds were not processed before sowing. For both crops, winter wheat was the predecessor on the experimental plots.

The active ingredient of Helicovex SK is a cotton bollworm's nucleopolyhedrovirus isolate BV-0003 [19] and the active basis of Virin HSK is the virus strain HS-18(RU patent $2511042 \mathrm{C} 1$ ). The concentration of the virus in Helicovex SK is $7.5 \times 10^{12}$ polyhedron/l, while Virin HSK has a concentration of $2 \times 10^{12}$ polyhedron/1. Both products have a formulation of suspension concentrate. Pirinex KE is an organophosphate contact-intestinal insectoacaricide with an active substance of chlorpyrifos in a concentration of $480 \mathrm{~g} / \mathrm{l}$ formulated as emulsion concentrate. It is recommended for use against all types of family Noctuidae (including cotton bollworms).

The crops were treated in the second and third ten-day periods of July. The following treatment flow rates were used: Helicovex SK - $100 \mathrm{ml} / \mathrm{ha}$; Helicovex SK - $200 \mathrm{ml} / \mathrm{ha}$; Virin HSK - $150 \mathrm{ml} / \mathrm{ha}$; Pirinex, KE - $2.0 \mathrm{l} / \mathrm{ha}$; and control - untreated plot. The number of insects and the damage caused by them were evaluated using the procedure used for registration tests. (Russian Standard - Dolzhenko et al., 2004).

The studied period of protective action was 14 days after the second treatment. Weather conditions during treatment were the following: air temperature $-(23 \pm 1){ }^{\circ} \mathrm{C}$, relative air humidity - $(66 \pm 2) \%$; wind speed - $(1.5 \pm 0.5) \mathrm{m} / \mathrm{sec}$.

Pheromone traps were used to monitor the cotton bollworms and determine optimal treatment time. Spring was wet with thermal discontinuities, which resulted in plant and insect phenophase shifts. The flight of the overwintered generation of cotton bollworms began to fly in early June and reached its peak by the middle of the first ten-day period of June. The first summer generation began flying in the middle of July and gradually increased its numbers.

Corn was first treated on July 17 (Zad.71 stage of plant development: ripening, milk stage), and soybean was first treated on July 18 (Zad.89 stage of plant development: seed ripening). Active flying of butterflies and caterpillar hatching were observed in this period. 
The treatments aimed to prevent the penetration of hatched caterpillars into cobs and beans. The treatments were carried out after 7 PM. On July 20 (3rd and 2nd day after corn and soybean treatment, respectively) there were 5.6-6.0-mm precipitations. Both crops were repeatedly treated with Helicovex SK 7 days after the first treatment. Virin HSK and Pirinex KE were applied only once.

The biosafety of the bioinsecticides was tested in laboratory using ectoparasite Habrobracon hebetor (Say, 1836) (Hymenoptera, Braconidae) that is massively used against cotton bollworm [20].

Compatibility of bioinsecticides and Pirinex KE with gabrobrachon was studied in laboratory conditions using the cocoons of H. Hebetor Say

Middle-aged caterpillars of honeycomb moth (Galleria mellonela (Linnaeus, 1758)) were used as insect-host for laboratory cultivation of habrobracon. The caterpillars were placed in 0.5-1 glass jars and infected with the parasite. The jars were tightly covered with a coarse calico cloth with a cotton swab moistened with a $20 \%$ solution of sugar for entomophage nutrition and placed in a thermostat with a temperature of $+28-30{ }^{\circ} \mathrm{C}$. Cocoons of habrobracon formed after 7-8 days after infection. These cocoons were treated with recommended amounts of the following insecticides to protect corn from lepidopterous insects: Helicovex SK $\left(7.5 \times 10^{9}\right.$ polyhedron/1); Virin HSK $\left(1.5 \times 10^{9}\right.$ polyhedron/l), Pirinex KE (4.8 g/l). The experiment was performed three times.

We used t-test to determine if there is a significant difference between the means of groups (STATISTICA 6.0).

\section{Results}

Cotton bollworms on corn were calculated on the $10^{\text {th }}, 14^{\text {th }}$ and $21^{\text {st }}$ day after the first treatment (after single treatment in case of Virin HSK and Pirinex KE) during Zad.75, Zad.80 and Zad.85 plant development stages, respectively.

The number of caterpillars was determined on 15 cobs. Average numbers of caterpillars are given in table 1 .

Table 1. The average number of cotton bollworm caterpillars ( $\pm 95 \% \mathrm{CI})$ per 15 plants in corn samples, on $10^{\text {th }}, 14^{\text {th }}$, and $21^{\text {st }}$ days after the second treatment under conditions in 2017

\begin{tabular}{|l|c|c|c|c|}
\hline \multicolumn{1}{|c|}{ Option } & Flowrate, $\mathrm{ml} / \mathrm{ha}$ & 10th & 14th & $21 \mathrm{st}$ \\
\hline Control & - & $3.7(1.4)$ & $4.7(1.4)$ & $8.7(0.5)$ \\
\hline Helicovex SK 100 & 100 & $0.0(0.0)$ & $0.3(0.5)$ & $3.0(0.9)$ \\
\hline Helicovex SK 200 & 200 & $0.0(0.0)$ & $0.0(0.0)$ & $2.3(0.5)$ \\
\hline Pirinex KE & 2000 & $0.7(0.5)$ & $1.3(0.5)$ & $2.7(0.5)$ \\
\hline Virin HSK & 150 & $0.7(0.5)$ & $0.7(0.5)$ & $1.7(0.5)$ \\
\hline
\end{tabular}

On the $10^{\text {th }}$ day after the first treatment, the number of cotton bollworms in control was 3.6 caterpillars per 15 cobs. No caterpillars were found in the samples where Helicovex was used, while the average efficiency of Virin HSK and Pirinex KE was about $84 \%$ and $79 \%$, respectively.

After 14 days, the efficiency of Helicovex in both concentrations remained extremely high. Standard Pirinex KE and Virin HSK had the efficiency of $75 \%$ and $83 \%$, respectively.

After 21 days, the number of cotton bollworms in control continued to increase and accounted for 8.6 caterpillars per 15 cobs. The efficiency of Helicovex at a concentration of $200 \mathrm{ml} /$ ha and $100 \mathrm{ml} /$ ha fell to $75 \%$ and $67 \%$, respectively. The efficiency of Perinex KE and Virin HSK decreased to $68 \%$ and $82 \%$, respectively. 
For soybean, the efficiency of the products was first determined on $30^{\text {th }}$ day after the 1 st treatment, when soybean reached Zad 95 development phase (maturation). The efficiency of the products was determined by examining the damage of beans in lower, middle and upper stories of 4 plants in each experiment.

The second assessment was performed by the harvest. The biological yield of soybean was determined by counting soybean grains in 4 samples on 1-square-meter plots in each experiment with a subsequent extrapolation of the results for 1 hectare.

The findings given in table 2 show that Helicovex SK is effective against cotton bollworms at the flow rates of 100 and $200 \mathrm{ml} /$ ha and bean damage was 79.3-83.7 \% lower than in control. Virin HSK and Pirinex KE reduced the damage by $75.8 \%$ and $68.8 \%$, respectively.

Table 2. The percentage of damage to soybeans ( $\pm 95 \% \mathrm{CI})$ after treatment with insecticides, the level of reduction of soybean damage compared to the control (in percent $\pm 95 \% \mathrm{CI}$ ) and the yield of experimental fields (quintals/ha $\pm 95 \% \mathrm{CI}$ ) under conditions in 2017

\begin{tabular}{|l|c|c|c|c|}
\hline Option & $\begin{array}{c}\text { Flowrate, } \\
\mathrm{ml} / \mathrm{ha}\end{array}$ & $\begin{array}{c}\text { Damaged to } \\
\text { soybeans }\end{array}$ & $\begin{array}{c}\text { Reducing } \\
\text { damage }\end{array}$ & Yield \\
\hline Control & - & $21.0(1.6)$ & - & $18.4(1.2)$ \\
\hline Helicovex SK 100 & 100 & $4.2(0.4)$ & $79.9(2.1)$ & $24.1(0.4)$ \\
\hline Helicovex SK 200 & 200 & $3.3(0.5)$ & $84.2(2.8)$ & $24.7(0.8)$ \\
\hline Virin HSK & 150 & $4.8(0.6)$ & $77.1(3.4)$ & $23.6(0.3)$ \\
\hline Pirinex KE & 2000 & $6.6(2.7)$ & $68.8(16.0)$ & $22.6(0.8)$ \\
\hline
\end{tabular}

The biological yield of grain was 24.7 quintals/ha for Helicovex SK with a flow rate of $200 \mathrm{ml} / \mathrm{ha}$. Virin HSK with a flow rate of $150 \mathrm{ml} / \mathrm{ha}$ had a yield of 23.6 quintals/ha compared to 22.6 quintals/ha for Pirinex CE and 18.4 quintals/ha for control.

The findings on baculovirus safety show that the bioinsecticides are absolutely nontoxic to entomophages, while chemical insecticide Pyrinex EC leads to complete death of entomophages (Table 3).

Table 3. The average number of $H$. hebetor cocoons processed $( \pm 95 \% \mathrm{CI})$, mean adult insect number that flew out of cocoons $( \pm 95 \% \mathrm{CI})$ on the $3 \mathrm{rd}, 5$ th, and 7 th day after treatment and total number of imagoes that flew out of cocoons under conditions in 2017

\begin{tabular}{|l|c|c|c|c|c|c|}
\hline Option & $\begin{array}{c}\text { Concentration, } \\
\text { PIB/1 }\end{array}$ & $\begin{array}{c}\text { Cocoons } \\
\text { processed }\end{array}$ & $3^{\text {rd }}$ & $5^{\text {th }}$ & $7^{\text {st }}$ & $\begin{array}{c}\text { Total } \\
\text { number of } \\
\text { imagoes }\end{array}$ \\
\hline $\begin{array}{l}\text { Helicovex } \\
\text { SK }\end{array}$ & $7,5 \times 10^{9}$ & $83.3(0.7)$ & $\begin{array}{c}22.3 \\
(3.6)\end{array}$ & $\begin{array}{c}39.7 \\
(2.4)\end{array}$ & $\begin{array}{c}21.3 \\
(3.5)\end{array}$ & $83.3(0.7)$ \\
\hline Virin HSK & $1,5 \times 10^{9}$ & $91.0(1.1)$ & $\begin{array}{c}22.3 \\
(2.4)\end{array}$ & $\begin{array}{c}54.0 \\
(2.0)\end{array}$ & $\begin{array}{c}14.7 \\
(2.4)\end{array}$ & $91.0(1.1)$ \\
\hline Pirinex KE & 4,8 Г/л & $87.7(0,7)$ & 0 & 0 & 0 & 0 \\
\hline Control & - & $93.0(1.1)$ & $\begin{array}{c}21.3 \\
(1.7)\end{array}$ & $\begin{array}{c}57.3 \\
(4.0)\end{array}$ & $\begin{array}{c}14.3 \\
(2.4)\end{array}$ & $93.0(1.1)$ \\
\hline
\end{tabular}

\section{Discussion}

The treatment of corn with Helicovex bioinsecticide at the flow rates of $100 \mathrm{ml} / \mathrm{ha}$ and $200 \mathrm{ml} /$ ha and Virin HSK reduced the number of cotton bollworms, which made it possible to protect corn crops at critical stages of plant life: from the beginning of wax ripening to harvesting. Notably, the highest efficiency of the Helicovex was achieved after the first treatment. The second treatment did not result in significantly higher efficiency, which may 
be due to abnormally hot weather during this period. The biological efficiency of Virin HSK remained almost unchanged and high throughout the study even after single treatment and markedly exceeded the efficiency of Helicovex and Perinex at the end of the $3^{\text {rd }}$ week.

Treatment of soybean with Helicovex SK at the flow rates of 100 and $200 \mathrm{ml} / \mathrm{ha}$ and with Virin HSK at the flow rate of $150 \mathrm{ml} / \mathrm{ha}$ effectively reduced the number of cotton bollworms. These treatments protected soybean crops during bean ripening period.

We observed no delay or acceleration of the agricultural culture phenophases after treatment. All tested flow rates of the products demonstrated no phytotoxicity.

The efficiency of Helicovex SK and Virin HSK was higher than of the Pirinex KE used as reference.

Thus, biopreparations based on different strains of nuclear polyhedrosis virus can be effectively used for biological control of Helicoverpa armigera both separately and in combination with entomophages within technologies of organic agriculture.

Studies were carried out in accordance with State Assignment № 075-00376-19-00 of the Ministry of Science and Higher Education of the Russian Federation as part of research on the topic № 0686-2019-0009.

This work was partially supported by the State grant № 075-00376-19-00 of the Ministry of science and higher education of the Russian Federation and the State grant of Rospotrebnadzor.

\section{References}

1. T.R. Glare, J. Caradus, W. Gelernter, T. Jackson, N. Keyhani, J. Kohl, P. Marrone, L. Morin, A. Stewart, Trends Biotechnol. 30, 250 (2012) doi: 10.1016/j.tibtech.2012.01.003

2. L.A. Lacey, D. Grzywacz, D.I. Shapiro - Ilan, R. Frutos, M. Brownbridge, M.S. Goettel, Journal of Invertebrate Pathology. 132, 1 (2015). doi: 10.1016/j.jip.2015.07.009

3. D. Grzywacz. In L.A. Lacey (Ed.). Microbial control of insect and mite pests: from theory to practice. - Amsterdam: Academic, p. 27-46 (2016).

4. E. Fuller, B.D. Elderd, G. Dwyer, Am. Nat. 179, E70 (2012). doi: 10.1086/664488

5. V. Ilyinykh, O. V. Polenogova, Problems of Virology. 61, 85 (2016). DOI: 10.18821/0507-4088-2016-61-2-85-88

6. F. Moscardi, M.L. de Souza, M.E.B. de Castro, M.L. Moscardi, B. Szewczyk. In I. Ahmad et al. (Eds.). Microbes and microbial technology. - Dordrecht: Springer, p. 415-445 (2011). DOI: 10.1007/978-1-4419-7931-5_16

7. R.H. Ffrench-Constant, Genetics. 194, 807 (2013). 10.1534/genetics.112.141895

8. S. Reid, L. Chan, M. Van Oers. In J.A. Morales - Ramos et al. (Eds.). Mass Production of Beneficial Organisms. - Amsterdam: Elsevier, 437 (2014)

9. Passarelli, Virology. 411, 383 (2011). doi: 10.1016/j.virol.2011.01.009

10. R. Harrison, K. Hoover. In F. Vega et al. (eds) Insect pathology, 2nd edn. New York: Elsevier, p. 73-131 (2012)

11. R. Lapointe, D.K. Thumbi, C.J. Lucarotti. In S. Soloneski et al. (Eds.). Integrated Pest Management and Pest Control. - Rijeka, Croatia: InTech Open Access Publisher, p. 481-522 (2012). DOI: 10.5772/31389

12. A.V. Kolosov, T.A. Kosogova, L.E. Bulychev, A.N. Sergeev, Problems of Virology. 5, 43 (2010). PMID: 21260997

13. Fontes, H. Hartikainen, C. Williams, B. Okamura, Parasit Vectors. 10, 542 (2017). doi: $10.1186 / \mathrm{s} 13071-017-2495-8$

14. A.R. Panazzi, Neotrop. Entomol. 42, 119 (2013). DOI: 10.1007/s13744-013-0111-y 
15. D. Grzywacz, P.C. Stevenson, W.M. Mushobozi, S. Belmain, K. Wilson, Food Secur. 6, 71 (2014). DOI: 10.1007/s12571-013-0313-5

16. S. Haase, A. Sciocco - Cap, V. Romanowski, Viruses. 30, 2230 (2015). doi: $10.3390 / \mathrm{v} 7052230$

17. G.V.R. Rao, Ch. S. Kumar, K. Sireesha, P.L. Kumar. In K.S. Sree et al. (Eds.). Biocontrol of Lepidopteran Pests, Soil Biology. - Switzerland: Springer International Publishing, 11 (2015). DOI: 10.1007/978-3-319-14499-3 2

18. X. Sun, Viruses. 7, 306 (2015). doi: 10.3390/v7010306

19. Proposed registration decision, 1925-0886 ; PRD2018-08. Helicoverpa armigera nucleopolyhedrovirus isolate BV-0003 and Helicovex

20. I.S. Agas'eva, M.V. Nefedova, E.V. Fedorenko, A.O. Mkrtchyan, A.S. Nastasii, V.Ya. Ismailov, (2019) Sel'skokhozyaistvennaya Biologiya, 54, 101 (2019). doi: 10.15389/agrobiology.2019.1.101rus 
Vladimir ISMAILOV,

Владимир Исмаилов

E-mail: vlyaism@yandex.ru

All-Russian Research Institute of Biological Plant Protection, Federal Agency of Scientific Organizations, 39, Krasnodar, Russia

Всероссийский Научно-Исследовательский Институт Биологической Защиты Растений

Deputy Director for scientific research and innovation

Заместитель директора по научной работе и инновациям

Irina AGASJEVA,

Ирина Агасьева

E-mail: Agasieva5@yandex.ru

All-Russian Research Institute of Biological Plant Protection, Federal Agency of Scientific Organizations, 39, Krasnodar, Russia

Всероссийский Научно-Исследовательский Институт Биологической Защиты Растений

Leading researcher

Ведущий научный сотрудник

\section{Grigory ANANKO}

Григорий Ананько

8 (913) 892-30-36

E-mail: ananko_gg@vector.nsc.ru

FBRI State Research Center of Virology and Biotechnology "Vector" Rospotrebnadzor 630559, Koltsovo, Novosibirsk region, Russia

Государственный Научный Центр Вирусологии и Биотехнологии «Вектор» Роспотребнадзора

Senior researcher

Старший научный сотрудник

Alexey KOLOSOV

Алексей Колосов

8 (913) 380-35-03

kolosov@vector.nsc.ru

FBRI State Research Center of Virology and Biotechnology "Vector" Rospotrebnadzor 630559, Koltsovo, Novosibirsk region, Russia E-mail:

Государственный Научный Центр Вирусологии и Биотехнологии «Вектор» Роспотребнадзора

Leading researcher

Ведущий научный сотрудник 